\title{
Reading the Grand Tour at a Distance: Archives and Datasets in Digital History
}

\author{
Jason M. Kelly
}

Giovanna Ceserani has made important contributions to the history and historiography of the Grand Tour through her publications, most notably her 2012 work on the archaeology of Magna Græcia during the eighteenth century. ${ }^{1}$ In her new work, part of the larger Mapping the Republic of Letters project at Stanford University, she focuses on using large datasets to map the social networks of the Grand Tour in Italy. In the case studies that make up Mapping the Republic of Letters, the research teams rely on standardized datasets, which are more easily extracted and developed from reference works such as biographical dictionaries, editions of correspondence, or digital indexes. In this case, the primary dataset is A Dictionary of British and Irish Travellers in Italy, 1701-1800 (DBIT), supplemented with information from the 4th edition of Howard Colvin's A Biographical Dictionary of British Architects, $1600-1840 .^{2}$ The work that Ceserani and her colleagues are doing, which they detail in the preceding article in this forum, provides a way to focus our thinking about the limits and potentials of digital history, especially as they relate to the archive, the construction of datasets, and data analysis. ${ }^{3}$

The history of the Grand Tour has a relatively recent provenance. It began drawing the interest of art and architectural historians only in the 1950s. ${ }^{4}$ In the 1990 s, the "cultural turn” in historical research led to an interdisciplinary explosion of works on the topic. ${ }^{5}$ This was complemented by new developments in art historiography and the installation of a series of highprofile exhibitions. ${ }^{6}$ Research produced by scholars across the disciplines since then has shown

This is the author's manuscript of the article published in final edited form as:

Kelly, J. M. (2017). Reading the Grand Tour at a Distance: Archives and Datasets in Digital History. The American Historical Review, 122(2), 451-463. https://doi.org/10.1093/ahr/122.2.451 
that the Grand Tour was an important element of the eighteenth-century world of letters. ${ }^{7}$ For example, the literary and artistic discussions of the Greek-Roman debate in the 1740s-1760s embodied deeply philosophical arguments over human nature, sensibility, the history of art, scientific methodology, and the order of the natural world. ${ }^{8}$ Not only did the world of Grand Tour letters play a role in broader philosophical discussions, but it also influenced tastes, fashions, and aesthetic attitudes for elites across Europe. ${ }^{9}$ Moreover, participation in the Grand Tour shaped and reshaped social structures and expectations across a host of realms—-from the world of sociability to gender norms to nationalist attitudes.

Since it was a social and intellectual experience that influenced generations of scholars, politicians, and well-to-do elites—one that instituted cultural connections across borders and large distances-research on the Grand Tour necessarily intersects with recent debates over the nature of the Enlightenment (or Enlightenments, depending on one's preferred interpretation). For the most part, however, the two historiographies have tended to follow separate paths. By bringing them together under the umbrella of the Mapping the Republic of Letters project, the Grand Tour Project has the potential to yield significant insights into the nature of the Enlightenment as an "intellectual project," as a cluster of social phenomena, as a territory for self-fashioning, and as a spatial construction.

In the sample presented in their article in this forum, Ceserani and her colleagues have built a case study around several dozen British architects. The data on architects who traveled to Italy during the eighteenth century is comparatively rich. ${ }^{10}$ Many of these men traveled with hopes of using the experience to improve their status in the profession and to find potential patrons. Because of their professional interests, most of these individuals were distinct from the 
average tourists, who were generally elites who used the opportunity to build their social networks and cultural capital.

The Grand Tour Project team has used the DBIT dataset to provide two types of pictures. First, they offer a visualization of where architects visited or lived while they were in Italy. Rather than display this as a GIS visualization, they offer a quantitative presentation, showing the comparative lengths of stay at any one location. The second series of visualizations consists of network analysis maps, focused on a number of social indicators: training and education, mode of income, membership in societies and academies, and governmental positions and honors. Ceserani et al. rightly observe that while there have been studies of individual architects on the Grand Tour-for example, the recent exhibitions at and accompanying volumes produced by the Victoria and Albert Museum and Bard Graduate Center on William Kent, James Stuart, and Thomas Hope- there has never been a comprehensive study of the social lives of British and Irish architects and their experiences on the Continent. ${ }^{11}$ Using the tools of the digital humanities, the team seeks to build a framework for this larger history.

Their method is a type of "distant reading," an approach most often associated with literary studies, and especially with the work of Franco Moretti, who coined the concept. ${ }^{12}$ Moretti notes that "distant reading” is "a process of deliberate reduction and abstraction.”13 Using a suite of computer-aided algorithms, it reduces the noise in a dataset for the purpose of identifying larger patterns. According to Moretti, these patterns are "a specific form of knowledge” that serves a complementary function to close reading. As Moretti’s work has demonstrated, the practice of distant reading can potentially identify new questions and problematize historical assumptions. 
However, it is important to note that using computer programs to analyze data can also reaffirm our assumptions and expectations. As the field of critical code studies has demonstrated, the process of framing questions and writing algorithms to answer them is not a neutral act. ${ }^{14}$ Algorithms can and do embody and reinscribe hierarchies of class, race, and gender. In the case of the DBIT, this potential is particularly acute given the nature of the dataset. Historicizing it and the intellectual framework from which it emerged provides insights into both the limits and the potentials of digital datasets for historical analysis.

The origins of the Dictionary of British and Irish Travellers in Italy can be traced to the early 1950s. It was originally the project of Sir Brinsley Ford, a wealthy young collector who had served in MI9 during World War II. While examining the backgrounds of the artworks in his collection, he developed an interest in the history of British collecting and began compiling an archive on eighteenth-century British and Irish travelers to Italy. ${ }^{15}$ He intended it to become a reference work, but for decades the projected volume remained unfinished as he and his collaborators continued to collect information on the thousands of travelers who visited the Italian peninsula over the century. In 1988 Ford donated his archive to the Paul Mellon Centre for Studies in British Art, and over the next decade, two editors, Kim Sloan (1988-1992) and John Ingamells (1992-1997), brought the work to publication.

Ford's archive—and the reference work that emerged from it—was the product of a decades-long shift in aesthetic criticism, connoisseurship, and art-historical scholarship in Britain. As the art world had developed in Britain since at least the seventeenth century, the world of the collector and aesthete and that of the philosopher and art scholar were closely integrated. However, the influence of Giovanni Morelli on stylistic research; the emphasis on 
archival work charted by Joseph Archer Crowe and Giovanni Battista Cavalcaselle; the disassociation of moral philosophy from aesthetics by Walter Pater, Oscar Wilde, the "Aesthetic Movement," and modernists such as Roger Fry; and the emphasis on cultural history, philology, and iconography among the circle at the Warburg Institute created a new postwar world of art and art scholarship. ${ }^{16}$ The domain of the collector started to separate from that of the scholar. A new generation of art history experts took positions at cultural institutions and assumed the (still) few university professorships. These individuals placed a premium on rigorous scholarship —not just on the studied analysis of individual form and technique or personal intuition and feeling that had so often dominated the world of connoisseurship, but on the archive. Nikolaus Pevsner summed up this attitude in 1952: "To know your material is a matter of course; not to be taken in by imitation goes without saying. The job of the art historian as against the connoisseur only starts on a plane above that." 17

Ford was adept at navigating this new cultural milieu, in which he participated as both connoisseur and amateur scholar. And, in fact, his archive served as a bridge between his personal art interests and patterns of collecting and the institutions of art-historical scholarship. The information that he began to compile mirrored his growing interest in the social history of art-though his was of a quite different variety than that of Arnold Hauser or Frederick Antal. ${ }^{18}$ The design of his project mirrored that of Howard Colvin, a medievalist trained at University College London, who had begun to assemble a catalogue on English architects in the late 1930s. Colvin’s approach was “to apply to architecture the ordinary processes of historical scholarship we were learning in the History Department at UCL.” His methods were targeted directly against connoisseurs who he thought relied too heavily on stylistic attributions. Colvin published the first edition of his Biographical Dictionary of English Architects in 1954, seeking "to discourage the 
kind of irresponsible attributionism that had been so prevalent in the past." ${ }^{\text {19 }}$ His magisterial compilation set the model for twentieth-century reference works on art and architectural history.

Ford's approach likewise emphasized a commitment to the documentary record. He and his collaborators gathered their information both from archives and from secondary publications, which were often cross-checked against the manuscript record. The Ford archive itself grew to consist of thousands of folders, each labeled with the name of an individual traveler. In each folder were loose notes and sheets of paper with handwritten entries from archival work, pages from auction catalogues, and letters from correspondents. Each item was directly connected to a traveler and included that person's activities while on the Grand Tour. While some folders bulged with information, others contained the sole evidence for the existence of an individual.

As an intellectual project guided by the vision of a single person, Ford's archive was idiosyncratic, defined by both his sociocultural status and his personal preferences. Like a number of connoisseurs in the postwar world, he was fascinated by Georgian collections and collectors, a consequence, in part, of the rise of the heritage industry, the activities of organizations such as the National Trust and the Georgian Group, and a cluster of advocates such as Christopher Hussey, Henry Avray Tipping, Ralph Dutton, 8th Baron Sherborne, and James Lees-Milne. Because Ford was a collector of fine art, his archive was, in his own words, primarily concerned with "matters connected with the arts, patronage [and] collecting." 20 The materials it contained reflected this. His work inscribed a metanarrative into the project—one in which the primary actors of the eighteenth-century Grand Tour were the elites, their lives and leisure pursuits, and the fine art that they collected and commissioned. Consequently, the social infrastructure of the Grand Tour — the labors of servants and valets, of artists and tutors and 
performers - was secondary to the primary aim of the project and relatively absent in the archive. This was not necessarily because Ford didn’t recognize the importance of these individuals. Rather, it was a by-product of the fact that his archive was determined by his social upbringing, his collecting interests, and a twentieth-century approach to art historiography that was primarily concerned with the work of the genius over that of the artisan, with the monumental artwork over the ephemeral, with the history of elites over that of their servants. To use an idea well-known to historians of the archive, the process of creating the Ford archive was both an act of remembering and an act of silencing and forgetting. ${ }^{21}$

In its design, the Ford archive was a living document, with new material and revisions being added regularly. The physicality of its interface reminded the user that the project remained a work in progress—rows of boxes stuffed with folders filled with paper objects, each representing an individual traveler. Its non-uniformity, its fragmentary objects, stressed not completeness, but absence. The researcher was left with the feeling that the project lacked every bit as much as it contained. And given the fact that there was no standard cataloguing scheme for cross-referencing or clustering people, things, or ideas, the archival experience was one of serendipity. There were notes scrawled onto a running list, one day in blue fountain pen, the next in dull pencil; another page, consisting of typewritten text on yellowing paper, had been taken out of a three-ring binder, its holes protected by adhesive reinforcements. The appearance and feel of the papers thus conveyed incompleteness, of an assemblage constantly being reshaped through the mind and actions of its compiler.

In the move to translate Ford's archive into the DBIT, the editors were obliged to impose a uniformity on the scattered references in the file folders. Brief notes became biographies, 
which conveyed a sense of coherence wholly absent in the archive. In the process, the DBIT effaced the materiality—and the inherent instability—of the archive creation process. If, as other scholars have argued, the process of archive-making is both an act of preservation and an act of knowledge production, then the process of transforming Ford's archive into an academic reference work further served to stabilize and reify this knowledge. In the case of the DBIT, the premises guiding the construction of Ford's archive remained. It still answered to a logic that privileged the interests and preferences of both the elite eighteenth-century travelers it described and the wealthy twentieth-century connoisseur who created it.

Yet, even as the editors translated the archive into the medium of the book, the intellectual framework on which the archival project was founded was being challenged. In the 1980s, the work of John Barrell, Ann Bermingham, and David Solkin, so important to eighteenth-century studies, called for a new social history of British art. ${ }^{22}$ Their approaches challenged scholars to put class and power at the center of their analyses. Reading eighteenthcentury works against the grain, they charted the social inequities and ideologies lurking within the visual field. On the heels of their work, the "cultural turn" encouraged scholars to write new histories of art in which gender and race were fundamental categories of analysis. ${ }^{23}$ The dictionary was unable to respond to these changes. In part, this was because of its long history. The information that Ford had gathered over the decades asked a different set of questions. But the medium of the book also played a role. As an analog technology, the printed book is useful for many things. It is particularly good for creating multiple static versions of a master copy. And it allows individuals some capacity to transform and interact with these versions through adding marginalia or inserting pages. However, universal updates are possible only by releasing new editions. These are expensive and therefore rare, especially in reference projects. The reference 
book is quite unlike an archive, which, while providing limited accessibility, can continue to be revised and grow, potentially answering new theoretical and historiographical questions. With the publication of the DBIT, the new volume displaced Ford's archive as the primary locus of information on the British Grand Tour for most scholars. And, consequently, two decades after its publication, the information that it contains has effectively supplanted the living archive. ${ }^{24}$

The organization of the DBIT makes it a useful tool from which to create a dataset. It provides some basic metadata, and the bibliographical sections can be broken down into unique records made up of a series of fields. For example, the entry for Nicholas Revett notes that he traveled to Naples with fellow artists/architects James Stuart, Gavin Hamilton, and Matthew Brettingham in 1748. A relational database could be configured to identify the links between the record "Nicholas Revett" and other records and data elements, in this case three individuals, one location, and one date.

The database scheme favored by the Mapping the Republic of Letters project is a descriptive model. By this we mean that once the datasets are structured and compiled, they remain relatively fixed. They might then be connected to other datasets through a "linked data" framework. ${ }^{25}$ There are other schemes, however, including the Itinera project at the University of Pittsburgh, directed by Drew Armstrong and Alison Langmead. ${ }^{26}$ Itinera is a non-period- or place-specific project that seeks to map the interactions between people, places, and art objects over time. Rather than design the project around an existing dataset, its creators began with two questions: How do we map historical art worlds using data that is both fragmentary and ambiguous? And how do we create a data structure that will grow as we incorporate new archival and visual fragments? From its outset, Itinera was meant to be an emergent dataset, with data 
being added regularly by the research team and their students, and ultimately through a process of peer-reviewed crowdsourcing. ${ }^{27}$

Like the Grand Tour Project, Itinera uses the DBIT as source material, but there it is only one source among many. Entries can come from any archive or reference work. Itinera will compile all references to a person or object and link them to a date and geographical location (though in its prototype form, it is not currently showing objects). The idea is to imagine a world not just of people, but of things in motion—letters, books, manuscripts, antiquities, objets d'art, textiles, and paintings. The circulation and exchange of these items was fundamental to forging and sustaining the sociocultural networks of the early modern world of letters. The symbolic information that these objects conveyed, whether mathematical, historical, or aesthetic, helped shape new intellectual communities, even as the meanings transformed in the face of local knowledges, rhetorics, social practices, and cultural lexicons. In effect, objects will become primary players in the historical narrative presented in Itinera.

The philosophical framework guiding Itinera emerged from the cluster of approaches associated with Actor-Network-Theory. ${ }^{28}$ The project de-centers the human subject, making individuals and things "actants" - with their own distinct pasts and capacities to have historical agency. Following the trajectory of these actants in the system can reveal the biographies of things as well as the network of relationships that they have with other things, people, and places. Consequently, Itinera will allow users to map not only the geography and chronology of an artwork, but its interactions with other actants. While it integrates the data from the DBIT, it will not be limited by it. 
There are other database schemes that could be created for the DBIT, their designs determined by the research question at hand and the availability of the data. Because the Ford archive privileged historical information about elite art interests over other information, this perspective will shape any dataset derived from it. Hidden in its schema—its fields, its relationships, its functions-is the original logic that drove the archive's construction. Ceserani and her colleagues are aware of these challenges, noting in their article that their visualizations "show us the shape as well as the limits of our data." Because of this, there are a series of questions related to the historiographies of the Grand Tour, the Enlightenment, and the Republic of Letters that remain out of the project's domain as currently framed.

The Grand Tour Project team does an admirable job asking questions of a dataset that is relatively unforthcoming with social history. Their approach suggests several directions for database-driven research on the Grand Tour that could provoke new questions. For example, the political culture of the Grand Tour is still relatively underdeveloped, but it is clear that at least a few artists and architects had patronage networks that were closely tied to their Hanoverian or Jacobite sympathies..$^{29} \mathrm{~A}$ case in point was James Russel, a long-term resident artist and ciceroni who was closely affiliated with Jacobite circles while resident in Rome. ${ }^{30}$ With the geographical and time data for each architect, one could co-locate each individual with other architects and artists. (A division between architects and artists is a somewhat arbitrary division, since while in Italy they were often closely associated with each other.) This information could then be crossreferenced to known associates, patrons, and their political affiliations, which in many cases are noted in the DBIT. This approach has the potential to identify previously unnoticed patterns of political association and cultural production. 
Likewise, the larger social networks and patterns of the Grand Tour specifically, and the Republic of Letters more generally, could be greatly expanded by bridging the Italian, French, German, Dutch, British, and Irish communities. Works on the Grand Tour have tended to focus on distinct national communities, ignoring the intersections and crossover between them. This is the case with the DBIT, which has entries for only a few prominent Italian individuals. Connecting British and Irish networks to the international community with which they were in regular communication would provide new ways to think about the Grand Tour as a cosmopolitan endeavor — and make it more relevant for debates over the nature of the eighteenthcentury world of letters. For example, there were prominent artists, such as Imperiali, Agostino Masucci, Giovanni Battista Busiri, and Marco Benefial, who operated at the center of AngloItalian artistic and patronage networks. ${ }^{31}$ Individuals such as Giovanni Battista Piranesi, Anton Raphael Mengs, and Johann Joachim Winckelmann participated with artists, architects, and other travelers in philosophical discussions that shaped neoclassical artistic theories throughout Europe. And intellectuals such as Antonio Cocchi were key interlocutors in scientific and literary debates. Analyzing these international connections also reveals a sort of reverse Grand Tour, of Italian scientists and writers, architects, artists, and musicians traveling north to Britain and Ireland. ${ }^{32}$ While documentation for some of these connections is thin, there remain numerous untapped resources (such as the dozens of volumes of diaries left by Cocchi that detail his dayto-day contacts with British and Irish travelers) that could demonstrate the international communities that the Grand Tour sustained. ${ }^{33}$

Still, even these questions are operating within a framework established by Ford. As the Grand Tour Project reveals, by and large artists and architects were laborers—privileged at times, but still operating within a commercial framework that was harsh and unforgiving. They 
were key participants in a labor system that helped to sustain the sociocultural infrastructure of the Grand Tour specifically and the Republic of Letters more generally. They hired themselves out as draftsmen, tutors, and guides. They participated in conversazione and sustained intellectual networks through letter-writing and visitations. Some even wrote important treatises that engaged with the rich philosophical debates of the age. ${ }^{34}$ But they did this primarily so that they could find patrons. For them, the Grand Tour was not simply a realm of pleasure and contemplation; it was a world of competition, which could be cutthroat at times. Russel, for example, was sometimes forced to sell his drawings at well below market value so that he could survive. On one occasion, he wrote home requesting his family to send him a "good large Cheshire-cheese; which I assure you will be a very acceptable utensil in these hungry times.”35 His financial situation could cause him to be a fierce operator, especially when it came to those whom he saw as competition. ${ }^{36}$ Like so many of his fellow artists and architects, he operated in a liminal social space that afforded him the right to participate in forms of elite sociability but did not recognize him as a social equal. Despite the difficulties many of them faced, the lives of artists and architects existed in the most privileged tier of the Grand Tour labor system. Others, most obviously valets and servants, innkeepers, tavern workers, coachmen, sex workers, actors, singers, stagehands, cooks, tailors, guides, diggers, physicians, and secretaries, also overlapped with the pursuits of those elites described in the DBIT.

There was an even broader network of labor that supported the Grand Tourists— especially their spending sprees on art and antiquities to fill their newly constructed and refurbished country houses. The extent and details of this labor network are only just beginning to be investigated by scholars. At the forefront of this research is the Legacies of British SlaveOwnership (LBS) project at University College London. ${ }^{37}$ By compiling a database of the Slave 
Compensation Commission's records from the 1830s, LBS has begun to reveal the close associations between slavery, slaveholders, and elite consumption during the eighteenth and early nineteenth centuries. The project's directors and a handful of other scholars are in the process of demonstrating the connections between plantation slavery and the economies of conspicuous consumption and display. ${ }^{38}$

Connecting the information in the DBIT to that emerging from projects such as LBS would reveal a fundamentally different "distant reading” of the Grand Tour—one that identified new transatlantic economic, cultural, political, and social connections. Doing so would require scholars of the European world of letters to integrate a more diverse series of datasets and more robust network models. ${ }^{39}$ In fact, it would necessitate an entirely new set of research questions that considered the links between the Grand Tour, the world of letters, elite consumption and display, labor history, and the history of colonial slavery. Connecting data from the colonial archives and linking them to the DBIT would bridge the disconnect between the research questions that drove its construction and the new critical frameworks that have emerged since the 1980s — demonstrating that the Grand Tour functioned not just as a finishing school for elites or a system supporting the development of a cosmopolitan Republic of Letters, but as a system of power that reproduced sociopolitical hierarchies and was supported by a transnational infrastructure of subjugation. ${ }^{40}$

In considering the history of the Ford archive and its conversion into both the DBIT and the datasets and visualizations created by the Grand Tour Project, important methodological questions emerge for the practice of digital (and "digitized”) history. ${ }^{41}$ While there have been conversations in the digital humanities, historians in general have yet to engage in a broad 
discussion about best practices and research standards in the development and use of digital datasets. For example, despite the fact that the Grand Tour Project team has made its data available for this article, there are no general guidelines on whether we should share our datasets as addenda to our research outputs in order to provide a means to verify or replicate visualizations. Like archives, our datasets are assemblages with their own histories, but their lack of materiality and appearance of objective rationality have the tendency to hide the decisions, biases, and assumptions that frame them. As they enter digital repositories and become disassociated from the scholars who created them, datasets become unmoored from their histories and the epistemologies, institutions, and methods that determined their structure. In developing best practices, historians should consider the necessity of embedding reflexive analyses and historical information about a dataset's creation in its metadata. Likewise, in training the next generation of historical scholars, we need to develop new modes for analyzing datasets and critiquing the ontologies that frame them. The Mapping the Republic of Letters projects—in particular the Grand Tour Project's work—demonstrate the value of using big data in historical analysis. As case studies, they also encourage us to think about the limits of our data frameworks, new modes of implementation, and the ways in which digital methods might be employed to create a more robust historiographical ecology. 
Notes

${ }^{1}$ Giovanna Ceserani, Italy’s Lost Greece: Magna Graecia and the Making of Modern Archaeology (Oxford, 2012).

${ }^{2}$ John Ingamells, comp., A Dictionary of British and Irish Travellers in Italy, 1701-1800 (New Haven, Conn., 1997); Howard Colvin, A Biographical Dictionary of British Architects, 16001840, 4th ed. (New Haven, Conn., 2008).

${ }^{3}$ Giovanna Ceserani, Giorgio Caviglia, Nicole Coleman, Thea De Armond, Sarah Murray, and Molly Taylor-Poleskey, "British Travelers in Eighteenth-Century Italy: The Grand Tour and the Profession of Architecture,” this issue.

${ }^{4}$ Before the 1950s, there were few works concerned with the Grand Tour as a focus for research. Exceptions included William Edward Mead, The Grand Tour in the Eighteenth Century (Boston, 1914); E. M. Hutton, “The Grand Tour in Italy: In the Sixteenth, Seventeenth and Eighteenth Centuries” (Ph.D. thesis, Cambridge University, 1937); R. S. Lambert, ed., Grand Tour: A Journey in the Tracks of the Age of Aristocracy (New York, 1937); Constantia Maxwell, The English Traveller in France, 1698-1815 (London, 1932). By the 1950s, a series of articles and books represented the interest in eighteenth-century travelers, their collections, and the world of settecento Italy: Paul Franklin Kirby, The Grand Tour in Italy, 1700-1800 (New York, 1952); John Stoye, English Travellers Abroad, 1604-1667: Their Influence in English Society and Politics (New York, 1952); James Boswell, Boswell on the Grand Tour: Italy, Corsica, and France, 1765-1766 (London, 1955); C. P. Brand, Italy and the English Romantics: The Italianate Fashion in Early Nineteenth-Century England (Cambridge, 1957); Charles F. Mullett, “Englishmen Discover Herculaneum and Pompeii,” Archaeology 10, no. 1 (1957): 31-38; 
Brinsley Ford, "Italy and the Grand Tour at Norwich,” The Burlington Magazine 100, no. 666 (1958): 316-319.

${ }^{5}$ Representative works include Edward Chaney, The Evolution of the Grand Tour: Anglo-Italian Cultural Relations since the Renaissance (e-book ed., London, 2014); Rosemary Sweet, Cities and the Grand Tour: The British in Italy, c. 1690-1820 (Cambridge, 2012); Paula Findlen, Wendy Wassyng Roworth, and Catherine M. Sama, eds., Italy's Eighteenth Century: Gender and Culture in the Age of the Grand Tour (Stanford, Calif., 2009); Bruce Redford, Dilettanti: The Antic and the Antique in Eighteenth-Century England (Los Angeles, 2008); Jason M. Kelly, The Society of Dilettanti: Archaeology and Identity in the British Enlightenment (New Haven, Conn., 2009); Carole Paul, The Borghese Collections and the Display of Art in the Age of the Grand Tour (Burlington, Vt., 2008); Jeremy Black, Italy and the Grand Tour (New Haven, Conn., 2003); John Eglin, Venice Transfigured: The Myth of Venice in British Culture, 16601797 (New York, 2001); Viewing Antiquity: The Grand Tour, Antiquarianism and Collecting, Special Issue, Ricerche di Storia dell'arte 72 (2000); Frank Salmon, Building on Ruins: The Rediscovery of Rome and English Architecture (Burlington, Vt., 2000); Clare Hornsby, The Impact of Italy: The Grand Tour and Beyond (London, 2000); Shearer West, ed., Italian Culture in Northern Europe in the Eighteenth Century (Cambridge, 1999); Chloe Chard, Pleasure and Guilt on the Grand Tour: Travel Writing and Imaginative Geography, 1600-1830 (Manchester, 1999); Andrew Wilton and Ilaria Bignamini, Grand Tour: The Lure of Italy in the Eighteenth Century (London, 1996); Bruce Redford, Venice and the Grand Tour (New Haven, Conn., 1996); Jason M. Kelly, “Letters from a Young Painter Abroad: James Russel in Rome, 174763,” The Volume of the Walpole Society 74 (2012): 61-164; David Ryley Marshall, Susan May 
Russell, and Karin Elizabeth Wolfe, eds., Roma Britannica: Art Patronage and Cultural Exchange in Eighteenth-Century Rome (London, 2011).

${ }^{6}$ Particularly influential were Grand Tour: The Lure of Italy in the Eighteenth Century (Tate Gallery, London, and Palazzo delle Esposizioni, Rome, 1996) and Vases and Volcanoes: Sir William Hamilton and His Collection (British Museum, London, 1997). Other representative exhibitions included The Italian Grand Tour in Letters, Journals, Books, and Prints (Beinecke Rare Book \& Manuscript Library, New Haven, Conn., 1998); Art Treasures in the North: Northern Families on the Grand Tour (Laing Art Gallery, Newcastle-upon-Tyne, 1999-2000); D’apres l'Antique (Musée du Louvre, Paris, 2000-2001); and Naples and Vesuvius on the Grand Tour, Rome on the Grand Tour, and Drawing Italy in the Age of the Grand Tour (Getty Research Institute Exhibition Gallery, Los Angeles, 2002).

${ }^{7}$ See, for example, Esther Mijers, “News from the Republick of Letters": Scottish Students, Charles Mackie and the United Provinces, 1650-1750 (Leiden, 2012); Willem Frijhoff, "Éducation, savoir, compétence: Les transformations du Grand Tour dans les Provinces-Unies à l'époque moderne," in Rainer Babel and Werner Paravicini, eds., Grand Tour: Adeliges Reisen und europäische kultur vom 14. bis zum 18. Jahrhundert (Ostfildern, 2005), 609-635; Tamara Anne Griggs, “The Changing Face of Erudition: Antiquaries in the Age of the Grand Tour” (Ph.D. diss., Princeton University, 2003).

${ }^{8}$ Johann Joachim Winckelmann, History of the Art of Antiquity (Los Angeles, 2006); Giovanni Battista Piranesi, Observations on the Letter of Monsieur Mariette: With Opinions on Architecture, and a Preface to a New Treatise on the Introduction and Progress of the Fine Arts in Europe in Ancient Times, trans. Caroline Beamish and David Britt (Los Angeles, 2002); Piranesi, The Polemical Works, Rome, 1757, 1761, 1765, 1769, ed. John Wilton-Ely 
(Farnborough, Hants., 1972); Christopher Drew Armstrong, Julien-David Leroy and the Making of Architectural History (New York, 2011); Kelly, The Society of Dilettanti; Mario Bevilacqua, Heather Hyde Minor, and Fabio Barry, eds., The Serpent and the Stylus: Essays on G. B. Piranesi (Ann Arbor, Mich., 2007); John A. Pinto, Speaking Ruins: Piranesi, Architects and Antiquity in Eighteenth-Century Rome (Ann Arbor, Mich., 2012); Lola Kantor-Kazovsky, Piranesi as Interpreter of Roman Architecture and the Origins of His Intellectual World (Florence, 2006); Susan Dixon, “The Sources and Fortunes of Piranesi’s Archaeological Illustrations,” Art History 25, no. 4 (2002): 469-487.

${ }^{9}$ On the reception of the Grand Tour, see Philip J. Ayres, Classical Culture and the Idea of Rome in Eighteenth-Century England (Cambridge, 1997); Jonathan Scott, The Pleasures of Antiquity: British Collectors of Greece and Rome (New Haven, Conn., 2003); Viccy Coltman, Fabricating the Antique: Neoclassicism in Britain, 1760-1800 (Chicago, 2006); Victoria C. Gardner Coates and Jon L. Seydl, Antiquity Recovered: The Legacy of Pompeii and Herculaneum (Los Angeles, 2007).

${ }^{10}$ They often kept journals and sketchbooks, and took commissions from wealthy travelers. As they attempted to build their careers in Italy, many were successful in attaching themselves to wealthy circles. As a result, their activities were recorded in the letters of patrons and their friends. And when they returned to Britain and Ireland, they were keen to advertise their experience through exhibitions, books, and the periodical press.

${ }^{11}$ Susan Weber Soros, ed., James “Athenian” Stuart, 1713-1788: The Rediscovery of Antiquity (New Haven, Conn., 2006); David Watkin and Philip Hewat-Jaboor, eds., Thomas Hope: Regency Designer (New Haven, Conn., 2008); Susan Weber, ed., William Kent: Designing Georgian Britain (New Haven, Conn., 2013). 
${ }^{12}$ Franco Moretti, “Conjectures in World Literature,” New Left Review 1 (2000): 54-68.

${ }^{13}$ Franco Moretti, Graphs, Maps, Trees: Abstract Models for Literary History (London, 2005), 1.

${ }^{14}$ Megan Garcia, “Racist in the Machine: The Disturbing Implications of Algorithmic Bias,”

World Policy Journal 33, no. 4 (2016/2017): 111-117; David Hankerson, Andrea R. Marshall, Jennifer Booker, Houda El Mimouni, Imani Walker, and Jennifer A. Rode, “Does Technology Have Race?," in CHI EA '16: Proceedings of the 2016 CHI Conference Extended Abstracts on Human Factors in Computing Systems (New York, 2016), 473-486; Tara McPherson, “U.S. Operating Systems at Mid-Century: The Intertwining of Race and UNIX,” in Lisa Nakamura and Peter Chow-White, eds., Race after the Internet (New York, 2012), 21-37; Lorna Roth, "Looking at Shirley, the Ultimate Norm: Colour Balance, Image Technologies, and Cognitive Equity,” Canadian Journal of Communication 34, no. 1 (2009): 111-136; Batya Friedman, ed., Human Values and the Design of Computer Technology (1997; repr., Stanford, Calif., 2004); Mark C. Marino, “Critical Code Studies,” Electronic Book Review, December 4, 2006, http://www.electronicbookreview.com/thread/electropoetics/codology; Marino, "Field Report for Critical Code Studies, 2014,” Computational Culture: A Journal of Software Studies, November 9, 2014, http://computationalculture.net/article/field-report-for-critical-code-studies2014\%e2\%80\%a8; Domenico Fiormonte, “Towards a Cultural Critique of the Digital Humanities,” Historical Social Research / Historische Sozialforschung 37, no. 3 (141) (2012): 59-76; Roopika Risam, “Beyond the Margins: Intersectionality and the Digital Humanities,” Digital Humanities Quarterly 9, no. 2 (2015), http://www.digitalhumanities.org/dhq/vol/9/2/000208/000208.html; Alan Liu, "Where Is Cultural Criticism in the Digital Humanities?,” in Matthew K. Gold, ed., Debates in the Digital Humanities (Minneapolis, 2012), 490-509, http://dhdebates.gc.cuny.edu/debates/text/20. 
${ }^{15}$ Brinsley Ford, John Ingamells, Francis Russell, John Christian, Nicholas Penny, Jennifer Montagu, Howard Coutts, Timothy Wilson, and Dudley Dodd, “Sir Brinsley Ford,” The Volume of the Walpole Society 60 (1998): 91-376, here 134.

${ }^{16}$ On Morelli’s methods, see Richard Wollheim, “Giovanni Morelli and the Origins of Scientific Connoisseurship,” in Wollheim, On Art and the Mind: Essays and Lectures (London, 1973), 177-201; Henri Zerner, “Giovanni Morelli et la science de l’art,” Revue de l’art 40-41 (1978): 209-215; Carlo Ginzburg, “Clues: Roots of an Evidential Paradigm,” in Ginzburg, Clues, Myths, and the Historical Method, trans. John and Anne C. Tedeschi (Baltimore, 1989), 96-125. On modernist art criticism and twentieth-century art history in Britain, see Mark A. Cheetham, Artwriting, Nation, and Cosmopolitanism in Britain: The 'Englishness' of English Art Theory since the Eighteenth Century (Farnham, Surrey, 2012); Griselda Pollock, “Art History and Visual Studies in Great Britain and Ireland,” in Matthew Rampley, Thierry Lenain, Hubert Locher, Andrea Pinotti, Charlotte Schoell-Glass, and Kitty Zijlmans, eds., Art History and Visual Studies in Europe: Transnational Discourses and National Frameworks (Leiden, 2012), 355378. On the Warburg Institute, see Felix Gilbert, "From Art History to the History of Civilization: Gombrich Biography of Aby Warburg,” Journal of Modern History 44, no. 3 (1972): 381-391; E. H. Gombrich, Aby Warburg: An Intellectual Biography (London, 1970); Edgar Wind, "Warburgs Begriff der Kulturwissenschaft und seine Bedeutung für die Ästhetik,” Zeitschrift für Ästhetik und allgemeine Kunstwissenschaft 25 (1931): 163-179, translated as “Warburg’s Concept of Kulturwissenschaft and Its Meaning for Aesthetics,” in Donald Preziosi, ed., The Art of Art History: A Critical Anthology, 2nd ed. (Oxford, 2009), 189-194; Richard Woodfield, ed., Art History as Cultural History: Warburg’s Projects (Amsterdam, 2001); 
Michael Diers, Thomas Girst, and Dorothea von Moltke, "Warburg and the Warburgian Tradition of Cultural History,” New German Critique 65 (1995): 59-73.

${ }^{17}$ Nikolaus Pevsner, “Reflections on Not Teaching Art History,” in Stephen Games, ed., Pevsner: The Complete Broadcast Talks-Architecture and Art on Radio and Television, 1945-1977 (London, 2016), 198-205, here 202.

${ }^{18}$ Ford's social history has much more in common with Nikolaus Pevsner's Academies of Art: Past and Present (Cambridge, 1940), which the author referred to in Pevsner, "Reflections on Not Teaching Art History,” 204, as a “social history of art.”

${ }^{19}$ Howard Colvin, “Writing a Biographical Dictionary of British Architects,” in Colvin, Essays in English Architectural History (New Haven, Conn., 2009), 292, 294. See also Anthony Geraghty, “Howard Colvin (1919-2007),” The Burlington Magazine 150, no. 1266 (2008): 613-614, here 614; Howard Colvin, A Biographical Dictionary of English Architects, 1660-1840 (London, 1954). Subsequent editions were expanded both chronologically and geographically. ${ }^{20}$ Ingamells, A Dictionary of British and Irish Travellers in Italy, xvi.

${ }^{21}$ On reading the archive, see Michel-Rolph Trouillot, Silencing the Past: Power and the Production of History, 2nd ed. (Boston, 2015); Ann Laura Stoler, “Colonial Archives and the Arts of Governance,” Archival Science 2, no. 1-2 (2002): 87-109; Carolyn Steedman, “Something She Called a Fever: Michelet, Derrida, and Dust,” American Historical Review 106, no. 4 (October 2001): 1159-1180; Jacques Derrida, “Archive Fever: A Freudian Impression,” trans. Eric Prenowitz, Diacritics 25, no. 2 (1995): 9-63; Michel Foucault, The Archaeology of Knowledge: And the Discourse on Language (New York, 1982). See also the literature review by Marlene Manoff, “Theories of the Archive from Across the Disciplines,” Portal: Libraries and the Academy 4, no. 1 (2004): 9-25. 
${ }^{22}$ Ann Bermingham, Landscape and Ideology: The English Rustic Tradition, 1740-1860

(Berkeley, Calif., 1989); John Barrell, "Sir Joshua Reynolds and the Political Theory of

Painting," Oxford Art Journal 9, no. 2 (1986): 36-41; Barrell, The Dark Side of the Landscape:

The Rural Poor in English Painting, 1730-1840 (Cambridge, 1983); David H. Solkin, Richard

Wilson: The Landscape of Reaction (London, 1982).

${ }^{23}$ David Bindman, “Blake’s Vision of Slavery Revisited,” Huntington Library Quarterly 58, no. 3/4 (1995): 373-382; Bindman, “Am I Not a Man and a Brother? British Art and Slavery in the Eighteenth Century,” Res: Anthropology and Aesthetics 26 (1994): 68-82; Chloe Chard and Helen Langdon, eds., Transports: Travel, Pleasure, and Imaginative Geography, 1600-1830 (New Haven, Conn., 1996); Marcia Pointon, Strategies for Showing: Women, Possession, and Representation in English Visual Culture, 1665-1800 (Oxford, 1997); Douglas Fordham, “New Directions in British Art History of the Eighteenth Century,” Literature Compass 5, no. 5 (2008): 906-917.

${ }^{24}$ For the universities that subscribe to it, a searchable digital version of the DBIT is available in the Adam Matthew Grand Tour database, http://www.amdigital.co.uk/m-products/product/thegrand-tour/. It replicates the model of the original dictionary, but it also links scanned copies of papers from the individual traveler files from the Ford Archive.

${ }^{25}$ For introductions to linked data, see "Linked Data—Connect Distributed Data across the Web," http://linkeddata.org; “Semantic Web,” W3C, https://www.w3.org/standards/semanticweb/; Tim Berners-Lee, James Hendler, and Ora Lassila, “The Semantic Web: A New Form of Web Content That Is Meaningful to Computers Will Unleash a Revolution of New Possibilities,” Scientific American 284, no. 5 (May 2001): 34-43, https://www.scientificamerican.com/article/the-semantic-web/. On the use of linked data in the 
Mapping the Republic of Letters project, see Glauco Mantegari, “Linked Data and the Republic of Letters," http://www.glaucomantegari.com/selected-projects/linked-data-and-the-republic-ofletters; Glauco Mantegari and Dan Edelstein, "Linked Data and Early-Modern Networks: An Experiment on Voltaire,” in Jake Coolidge, ed., The CESTA Anthology, 2013 (Stanford, Calif., 2013), 73-78, http://www.glaucomantegari.com/assets/docs/papers/CESTAAnthology2013_MantegariEdelstein.pdf.

${ }^{26}$ Itinera, University of Pittsburgh, https://itinera.pitt.edu.

${ }^{27}$ The distinction between descriptive and emergent datasets was a theme of the Network Ontologies in the Early Modern World Workshop held at the University of Pittsburgh on November 21-22, 2014 (https://sites.haa.pitt.edu/networkontologies/schedule-of-events/). The summary in the paragraph emerges from conversations at the workshop and an unpublished manuscript titled "The Pittsburgh Practices in Linked Historical Network Ontologies," ed. Elisa Beshero-Bondar, David Birnbaum, Alison Langmead, and Aisling Quigley from conversations among the workshop participants on November 22, 2014: Drew Armstrong, Mike Bolam, James Coleman, Mark Custer, Jason M. Kelly, Tom Lombardi, Jessica Otis, Adam Shear, Dan Shore, Chris Warren, and Scott Weingart.

${ }^{28}$ John Law and John Hassard, Actor Network Theory and After (Oxford, 1999); Bruno Latour, Reassembling the Social: An Introduction to Actor-Network-Theory (Oxford, 2007); Jane Bennett, Vibrant Matter: A Political Ecology of Things (Durham, N.C., 2010).

${ }^{29}$ See, for example, the work on Jacobite patronage in Rome during the eighteenth century:

David Irwin and Francina Irwin, Scottish Painters at Home and Abroad, 1700-1900 (London, 1975); Marion Amblard, "The Scottish Painters' Exile in Italy in the Eighteenth Century,” 
Études écossaises 13 (2010): 59-77; Edward Corp, The Stuarts in Italy, 1719-1766: A Royal Court in Permanent Exile (Cambridge, 2011), 7; Corp, “The Stuart Court and the Patronage of Portrait-Painters in Rome, 1717-1757," in David Marshall, Susan Russell, and Karin Wolfe, eds., Roma Britannica: Art Patronage and Cultural Exchange in Eighteenth-Century Rome (Rome, 2011), 39-53.

${ }^{30}$ Kelly, “Letters from a Young Painter Abroad,” 68-70.

${ }^{31}$ Jason M. Kelly, “Rome and Its British and Irish Artists, 1730-1750,” in Martin Postle and Robin Simon, eds., Richard Wilson and the Transformation of European Landscape Painting (New Haven, Conn., 2014), 41-42.

${ }^{32}$ West, Italian Culture in Northern Europe in the Eighteenth Century; Marta Cavazza, "The Institute of Science of Bologna and the Royal Society in the Eighteenth Century,” Notes and Records of the Royal Society of London 56, no. 1 (2002): 3-25; Reinhard Strohm, The Eighteenth-Century Diaspora of Italian Music and Musicians (Turnhout, 2001).

${ }^{33}$ Antonio Cocchi, Effemeridi, MSS ME361.1-103, Collezione è Fondo Cocchi, Biblioteca Biomedica dell’Università di Firenze.

${ }^{34}$ Eileen Harris and Nicholas Savage, British Architectural Books and Writers, 1556-1785 (Cambridge, 1990).

35James Russel to William Russel, October 27, 1750, British Library Add. MSS 41169, f. 51r.

${ }^{36}$ Kelly, "Letters from a Young Painter Abroad."

${ }^{37}$ Legacies of British Slave-Ownership, University College London, https://www.ucl.ac.uk/lbs/.

${ }^{38}$ Katie Donington, Ryan Hanley, and Jessica Moody, eds., Britain’s History and Memory of

Transatlantic Slavery (Liverpool, 2017); Madge Dresser and Andrew Hann, eds., Slavery and the British Country House (Swindon, 2013); Catherine Hall, Nicholas Draper, Keith McClelland, 
Katie Donington, and Rachel Lang, Legacies of British Slave-Ownership: Colonial Slavery and the Formation of Victorian Britain (Cambridge, 2014).

${ }^{39}$ Historians have yet to integrate complex models for historical social network analysis to any great extent. On the potential of this approach, see Scott Weingart's work, including his posts on “Networks Demystified” on his blog The Scottbot Irregular, http://scottbot.net/tag/networksdemystified/.

${ }^{40}$ On the complexities of this process, see Kim Gallon, "Making a Case for the Black Digital Humanities,” in Matthew K. Gold and Lauren F. Klein, eds., Debates in the Digital Humanities 2016 (Minneapolis, 2016), http://dhdebates.gc.cuny.edu/debates/text/55.

${ }^{41}$ Lara Putnam, “The Transnational and the Text-Searchable: Digitized Sources and the Shadows They Cast,” American Historical Review 121, no. 2 (April 2016): 377-402. Putnam argues that we have entered a moment in historical research in which not only has the digital turn taken root, but a more pervasive digitized turn has transformed how we work. The digital turn refers to various specialized approaches associated with the digital humanities, such as text mining, HGIS, and social network analysis. The digitized turn, on the other hand, suggests a more generalized set of transformations—-the ways that digitized databases, Google, and online image catalogues have reshaped historical methods—indeed, how they have reshaped our expectations about what scholars can accomplish in the scope of their studies. As Putnam observes, "we could not be doing what we are, at the pace that we are, with the range that we are, if it were not for the search box before us” (380). On this topic, see also Tim Hitchcock, "Digital Searching and the Re-formulation of Historical Knowledge,” in Mark Greengrass and Lorna Hughes, eds., The Virtual Representation of the Past (Burlington, Vt., 2008), 81-90. 